\title{
建築外部空間デザインの設計支援を目的とした熱収支・気流 連成シミュレーション手法開発の基礎的検討 \\ STUDY ON COUPLED SIMULATION SYSTEM OF HEAT AND AIR FLOW IN OUTDOOR SPACE FOR THE COMPUTER AIDED DESIGN TOOL
}

\author{
山村 真司*, 梅干野 昆**, 浅 輪 貴史*** \\ Shinji YAMAMURA, Akira HOYANO and Takashi ASAWA
}

\begin{abstract}
"A Coupled Simulation of Heat and Air Flow" is expected to be the computer aided design tool in outdoor space. Compared with the existing available prediction methods, this method herein described places greater emphasis on its ability to make it possible to evaluate thermal radiant environments, air temperature and wind distribution that are given to the timely prediction in design process as well as to various other factor including both variety of external materials and variety of exterior shapes.

This method was developed based on sensible heat balance simulation for all the exterior surface and standard $\mathbf{k}-\varepsilon$ turbulent Model. And sensible heat balance simulation is also combined with 3D-CAD system that makes it easily to input the complicated exterior shape and also make it possible to evaluate the 3-D distribution of surface temperature at any view points.
\end{abstract}

\section{Keywords: Outdoor Space, Computer Aided Design Tool, Heat Balance Simulation, CFD, Coupled Simulation} 建築外部空間、設計支援ツール、熱収支シミュレーション、気流シミュレーション、連成シミュレーション

\section{1. はじめに}

建築外部空間の環境は生活空間の場であると同時に、屋内熱環境 の形成に直接的な影響を及ぼす。このような建築外部空間において、 従来の設計実務の分野では、屋外の緑を視覚的なデザイン要素とし て位置付けするのが一般的であり、熱環境緩和を積極的に意識した 扱いがなされてこなかった。しかしながら今日では、設計者あるい は施主からの熱環境的にも有効なデザインの要望が高まりつつあ る。また、都市域ではヒートアイランド現象の進捗に伴い、年間を 通じての自然エネルギー利用による屋内空間の熱環境調整が困難 となる傾向にある。このような状況下、実務レベルにおける熱環境 緩和を配慮した、建物廻り〜街区スケールでの外部空間デザインの 計画・実現の普及が急がれるが、そのためには、設計実務の流れの 中での熱環境的なデザイン評価をより意識した設計支援手法の構 築と、それに基づいた予測評価手法の開発が必要である。

これに対して、既往の予測評価手法の開発状況は、以下を初めと

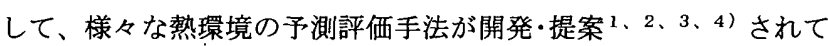
はいるものの、設計支援という点では、設計プロセスに対して未だ 十分に対応可能な状況には至っていない。
(1)村上ら $\left.{ }^{5} 、 6^{6}\right)$ は、3 次元対流・放射・湿気連成解析手法を開発して、 従来の $\mathrm{k}-\varepsilon$ モデルに比べて実現象のより再現性の高い風速·気温 分布予測を行っている。しかしながら、一連の物理現象を乱流モデ ルに組込んでの解析であるため、メッシュサイズに制約がでる点や、 空間構成材料及びその組み合わせ(土地被覆材料、樹木等)をパラメ トリックに変化させて熱的な影響分析を多数のケースで迅速に行 いデザインの試行錯誤を行いたい場合、CPU の能力に大きく制 約される問題などがある。

(2)谷本ら $\left.{ }^{7}\right)$ は、建築一都市一土壤連成系モデルを提案しているが、 1 次元熱収支モデルを適用しているため、空間構成材料の3 次元形 状の相違による熱的影響分析や、気流の空間分布が及ぼす影響の反 映等の点で、デザイン検討の自由度に制約が残る。

また、建築外部空間に形成される微気候は多様な要素が複雑に絡 み合っている。例えばデザイン検討の際、予測結果の平均風速が低 い場合、 $\mathrm{SET} *$ による快適性評価では不利となるが、乱れの強さに よる快適性への寄与は無視できない8）注11。一方で、平均風速の予 測結果から空間各所の乱れの強さを簡易に見積もることは困難な 状況にある。従って、予測手法構築に当たっては、平均風速等の一
* 東京工業大学大学院 工修 (侏)日建設部)

** 東京工業大学 教授. 工博

*** 東京工業大学大学院 修士 (工学)
Graduate Student, Tokyo Institute of Technology, M. Eng.

(Nikken Sekkei Ltd.)

Prof., Tokyo Institute of Technology, Dr. Eng.

Graduate Student, Tokyo Institute of Technology, M. Eng. 
連の物理現象を組み込み予測精度向上を図る手法開発もさること ながら、設計実務への適用を考虑した建築外部空間デザインの比較 検討を主眼に置いた予測評価手法の構築が必要である。

筆者らは、前述のような設計支援を意識して、まず建築外部空間 デザインによって直接的に規定される熱放射環境を扱うべく、3 D $-\mathrm{CADKよる}$ 空間形状入力〜 $0.2 \mathrm{~m}$ 均等メッシュによるメッシュ データ化〜1 次元熱伝導をもとにした空間全表面での熱収支計算に よる表面温度予測評価手法を開発している ${ }^{9)}$ 注2)。本研究では、さ らに表面温度分布と相互に影響を及ほしあう気温・気流分布も考慮 できるよう、建物廻り〜街区レベルのスケールを対象として、建築 外部空間デザインの実現化に重点を置いた設計支援手法を構築し、 それに基づく予測評価手法の開発を行うものである。

\section{2. デザイン䚽価に即した設計支援の方法と予測鲆価手法}

建築物及び建築外部空間の設計においては、通常、基本構想(企画) 〜基本設計〜実施設計というプロセスを経てプランを収斂させて いくが、各段階において要求される熱環境的な評価項目・レベルは 多様である。さらには、実際の設計作業では熱環境も含めて施主要 望、法規制など様々な要因に基づいてデザインの試行錯誤 ${ }^{0}$ 0) が行 われるため、設計プロセスに応じた迅速かつ効率的な熱的検証・設 計へのフィードバックが必要となる。また、設計実務者の $3 \mathrm{D}-$ C ADによるデザイン検討の過程 ${ }^{11}$ ) に合致させた形状入力及び予 測結果の出力方法等、簡便な取り扱いの考慮も重要な要素である。

予測評価結果の設計プロセスへの効率的な反映、設計過程での現 実的な支援をより意識した手法開発のためには、以下の項目を前提 とした検討を行う必要がある。

(1)対象となる外部空間スケール: 実務上、扱う頻度が比較的高い街
区スケール(数百 $\mathrm{m})$ ～住棟間スケール(数十 $\mathrm{m})$ にて、居住域レベル が対象となる。

(2)デザイン上評価対象とする空間構成要素 : 外部空間の居住域レベ ルを取り巻く外装材料、士地被覆材料、緑(種類、樹木形状・大きさ、量、 配直)、小スケールではあるが居住域放射環境に直接的に影響を及ほ す空間構成要素(庇、パーゴラ、ベランダ等)及びそれらの組み合わ せが対象となる。

(3)設計の各プロセスにおけける熱環境把握のニーズ : 一般的に、空間 デザインは、施主要望、コスト、動線計画、環境への配慮等あらゆ る要素をもとに収斂させていく。設計の段階が進むに従い、デザイ ンに対するこれら要素の制約が大きくなるため、予測・評価結果を フィードバックさせにくくなる。従って、図 1 に示すように、計画 の段階を追って適宜必要な予測・評価を行い、設計を支援出来方柔 軟な手法が必要である。例えば、基本構想段階では、建物群の配置 計画に際して通風性状やビル風等に関する評価結果をマスタープ ランに織り込む、基本訪画段階では、外装・土地被覆材料、植栽計 画の方針決定に際して、表面温度分布の観点から熱放射環境改善の 効果を把握するといっだ具合である注3)。

(4)設計支援に必要な評㑡・判断指標 : 外部空間構成要素をパラメト リックに変化させ、その熱的影響分析を検討する場合、SET *など の快適性指標 ${ }^{12)}$ だけでの判断では、快適性指標の相違に対して直 接要因となる空間構成要素（部材形状・材料など）が特定し難い場 合がある注1)。また、屋外居住域の熱放射環境が空間構成要素の相 違によって直接的に規穴される傾向も考慮すると、総括的なSET * による快適性評価とともに、表面温度(又は MRT)、平均風速、気温 ・ 湿度といった物理的指標による評価も含めて、設計プロセスの各段 階に応じて、デザインへのフィードバックに必要十分な評価指標を

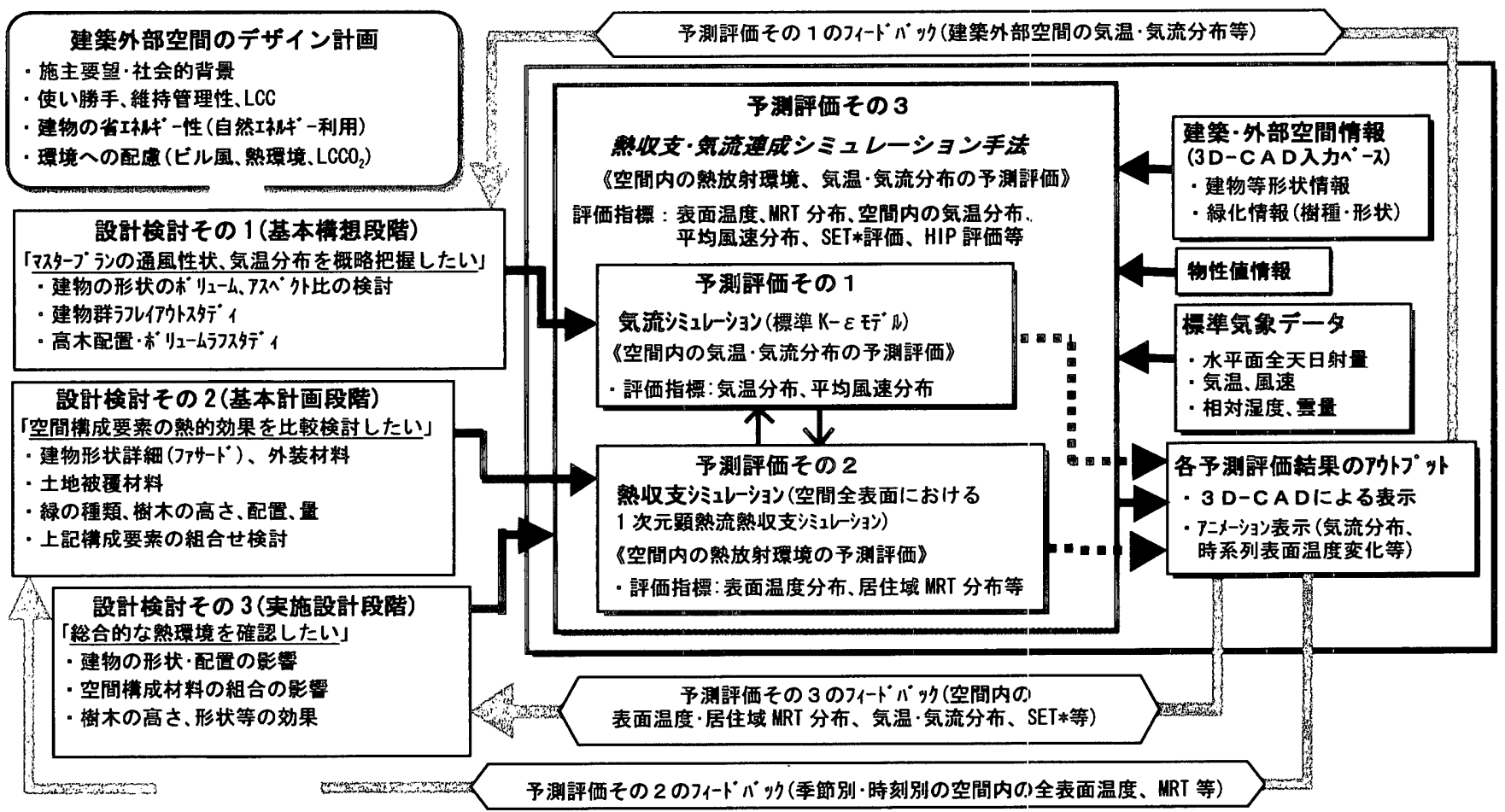

デザイン $\mathrm{IX}$

图 1 各設計プロセスにおける支援手法（予測評価手法）の関わりの一例注3） 


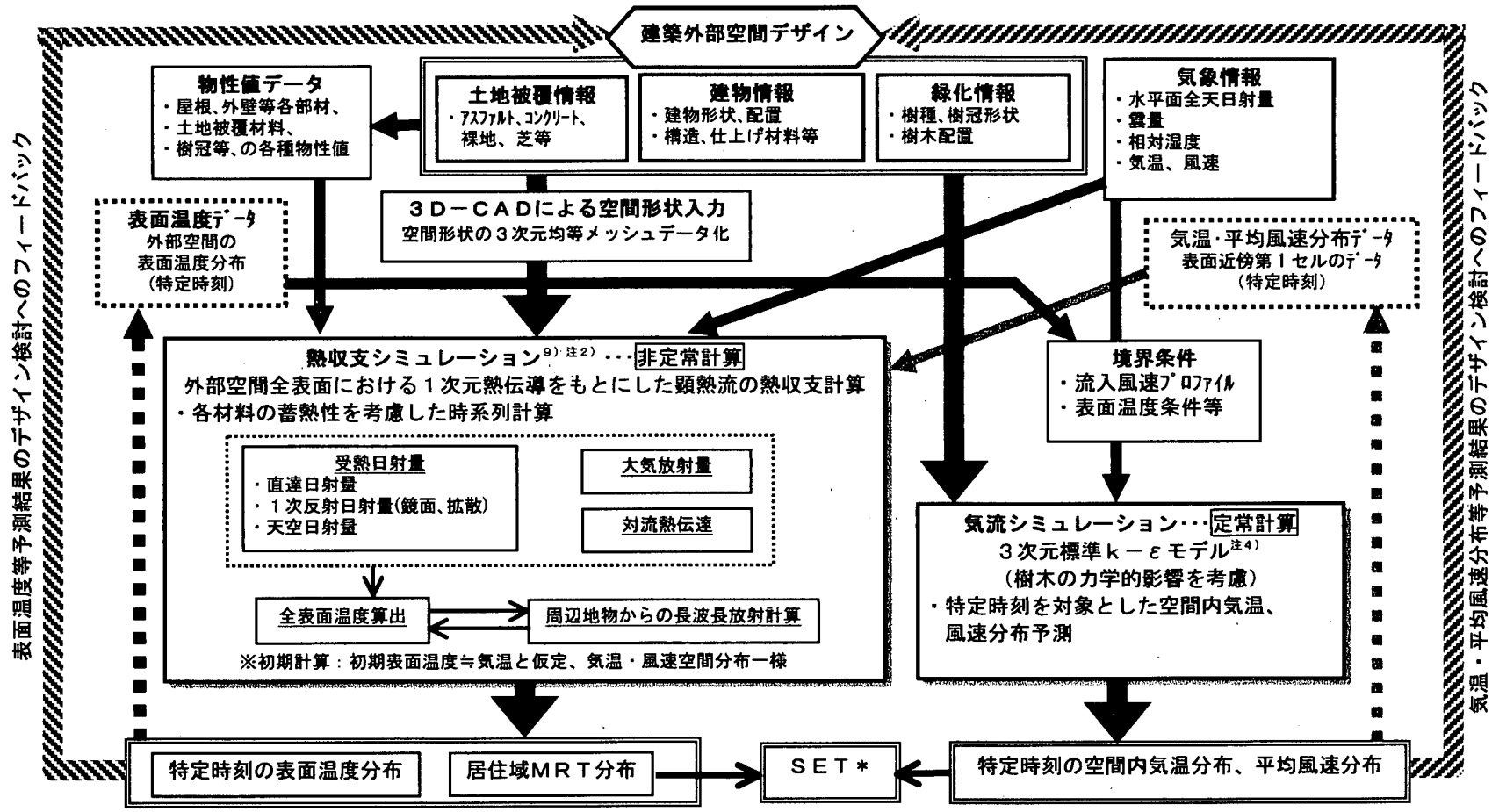

図 2 熱収支・気流連成シミュレーション手法のフレーム概要

適宜選択してて評価が出来るツール構成とすることで設計支援の柔 軟性・即応性はより高まると考える。

\section{3. 熱収支・気流連成シミュレーションによる予測評価手法の提案}

\section{1 連成予測評価手法の概要}

以上より、表面温度予測手法と空間内の気温·気流分布予測手法 の 2 つ方法を用いて、必要に応じてこれらを単独あるいは連成さ せて使用することで設計プロセスに対応可能な支援システムの構 築が可能と考える。本報では、筆者ら ${ }^{9}$ らが開発を行っている熱収 支シミュレーション注2) と、気流シミュレーション(標準 $\mathrm{k}-\varepsilon$ モデ ル)裎4）を各々独立した予測ツールとして連成を図った予測評価方 法(熱収支·気流連成シミュレーション手法)による設計支援システ 么を提案する（図 $1 、 2$ )。

本手法の特徵は、(1)設計プロセスにおける予測評価のタイミング と要求される評価対象(項目)に合わせてツール構成を柔軟に選択で きる点、(2)予測評価の目的に応じて、居住域レベルでの 3 次元空間 形状の相違を、計算上十分再現出来、かつ計算負荷を低减化させる ために、熱収支シミュレーション9、13)における空間全表面の均等 メッシュ化サイズと気流シミュレーションのメッシュサイズが 各々独立して設定でき、かつ表面温度等の境界条件が連携できるこ と、(3また、表面温度算出にあたっては、空間構成材料の熱放射環 境における影響分析を前提として、蓄熱効果を考慮した非定常計算 である点、(4)連成するにあたって、時系列での非定常計算(熱収支シ ミュレーション)と 1 時刻対象の定常計算(気流シミュレーション) の間のデータ受け渡しについて、設計支援上、予測精度と計算負荷 抑制とのバランスを考慮したデータのフィードバック方法の導入 等が挙げられる。

\section{2 連成予測評価手法構築のための検討事項}

時系列での全表面温度予測を行う熱収支シミュレーションと気 温・気流の空間分布把握を目的と寸る気流シミュレーション各々の 特徵を活かし、かつ設計支援を意識した連成手法を構築するために は以下をはじめとした様々な検討を行う必要がある。

(1)熱収支シミュレーションと気流シミュレーションとの間の形 状・サイズが異なるメッシュ間でのデータ受け渡し方法

(2)空間全表面を対象とした熱収支シミュレーションによる表面 温度算出にあたっての気温、平均風速の空間分布の考慮方法

(3)連成の具体的実施手法構築と、妥当な連成反復回数の抽出

(4)メッシュデータ化を前提とした熱収支シミュレーション及び 気流シミュレーション共通の $3 \mathrm{D}-\mathrm{CAD}$ A 力手法の構築注 5

(5)本連成手法に適用する樹木の力学的影響のモデル化手法注4) (6)湿気（潜熱）の扱い注6)

本研究では、(1) (3)について、方法論の構築と適用可能性の評価を 行うた。

\section{4. 連成手法における境界条件 (気温·風速·表面温度)の取り扱い}

4. 1 各ッールにおける異なるメッシュサイズ・形状間でのデー タ受け渡し方法

熱収支シミュレーションでは、庇、パーゴラなど小スケールであるが、居 住域の熱放射環境に大きな影響を及ぼす空間構成要素が垷まえられる3次 元均等メッシュサイズ $(0.2 \mathrm{~m})$ にて計算を行う。一方、気流シミュレー ションにおいては、計算負荷の点から、最小メッシュサイズは概水 $1 \mathrm{~m}$ 数 $\mathrm{m}$ オーダーであり、また、メッシュ形状も空間内の場所によって異なる。従 って、熱収支シミュレーションにて算出した表面温度を気流シミュレーショ ンの熱の境界条件として扱う場合、以下の受渡し手順を採用した（図3)。

(1)各気流解析メッシュが包含する熱収支計算メッシュの位置関係を 3 次 
元座標によって関車付ける。

(2)気流解析メッシュが包含する熱収支計算全メッシュの表面温度を面積

平均し、気流解析メッシュの表面温度条件とする。

(3)爸間内全表面にて、(1)、(2)を気流解析メッシュ每に絽り返寸

本方法では、樹冠による日影・日向の境界など著しい表面温度変化がある領 域では、データ受け渡し後、表面温度分布が滑らかなとなってしまうが、実 際には、当該部分での気温・風速が日影・日向によって大きな変化が見られ ないこから、定性的な分布傾向には大きな影響杖いものと判断した。

また、気流シミュレーションにて算出した気温、風速の空間分布を熱奴支 シミュレーションにおける各メッシュ毎の表面温度算出の参照データとす る場合は以下の方法にて受け渡しを行った。

(1) 地表面・壁面等に接する各気流解析メッシュと熱収支計算メッシュの 位置関係の関㔺付けは、上記” (1) “の方法に同じ。

(2)関連付けた気流解析メッシュの気温・風速を、当該メッシュが包含する

各熱奴支計算メッシュに一様に与える。これを空間全表面にて絽り返す。 なお、熱收支計算メッシュ毎に、受け渡された風速より Jurges の式にて対 流熱伝達率を求める力法注7) は、これまでの熱収支シミュレーション手法9) と同梯である。

\section{2 表面温度算出の際の気温・気流局所分布の反僢方法 （以降；定時解析手法）の提案}

本連成手法は、夏季の熱環境の悪化が予想される時間帯を特に解 析対象としているため、空間内の場所毎に材料の蓄熱を考慮した時 系列での計算が必要となる。

熱収支シミュレーション ${ }^{9)}$ による表面温度算出において、これま で筆者らは第 1 段階として、都市キャノピー内における気温、風速 の空間分布は一様 ${ }^{13)}$ として扱ってきた。しかしながら、居住域を 対象とする場合、日影・日向の分布に伴う気温の局所分布、ビル風。 縮流などによる風速の加速領域、建物風下の wake 内などの低風速 領域における対流熱伝達の相違などを相対的に考慮する必要があ る(図 4)。

その際、連成手法構筑上、気流シミュレーションで解析した 1 時 刻の気温・風速分布を如何にして表面温度算出のための時系列のデ 一タとして取り扱うかが問題となる。予測評価の対象とする時刻 (以降、着目時刻)にのみ分布のデータを与えたのでは空間内の各 場所における材料の蓄熱性の相違を十分には考慮していないこと になり、また多数の時刻分（例えば 24 時刻分）の解析を行ってい たのでは計算負荷量の点から設計支援という目的にそぐわない。

そこで、本手法では着目時刻とその直前 1 時刻ステップ前（着目 時刻の 1 時間（または 2 時間）前）の 2 つの時刻を対象に気流シミ ニレーションで解析した気温・風速分布をもとにして簡易的に局所 分布を考慮した時系列入力データを作成し、熱収支シミュレーショ ンを行う手法（以降、定時解析手法と呼ぶ）を提案する注8)。以下 でその有効性と適用可能範囲を検証する。

\section{3 定時解析手法の適用の検証}

前述のように、これまでの熱収支シミュレーション9) での都市キ ヤノピー上空の気象データ（時刻別気温・風速データ）を空間一様 の分布 ${ }^{13)}$ と仮定した表面温度予測に対して、例えば放射環境が劣 悪な居住域など、場所によっては上空気温と大きな気温差が生じる ことがある。気流分布についても同様である。

そこで、検討対象としたいくつかの街区モデルのうち、上空と空

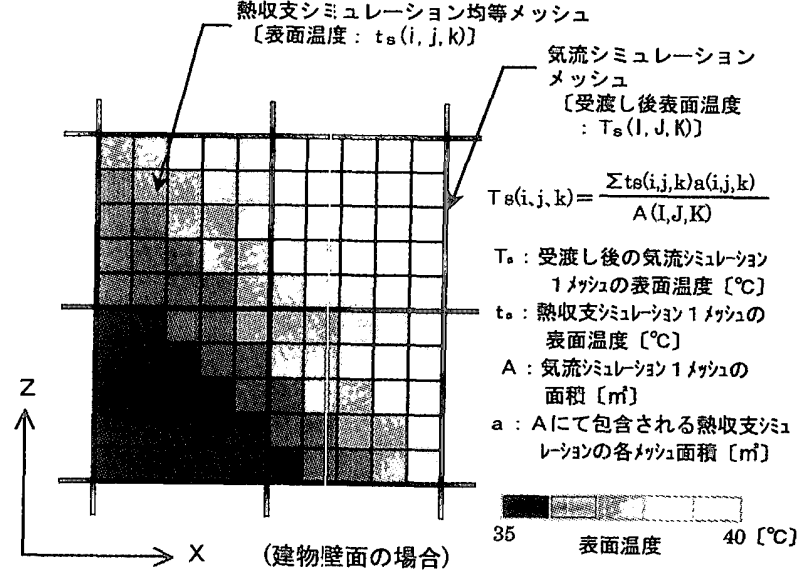

図3 熱収支シミュレーションにて算出した表面温度の 氮流シミュレーシションタッシュへの受け渡し例

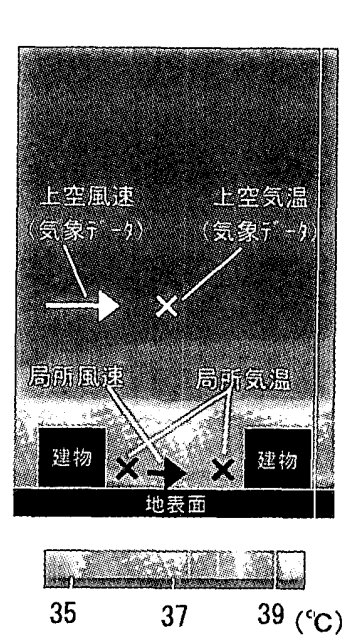

気温・風速の空間分析

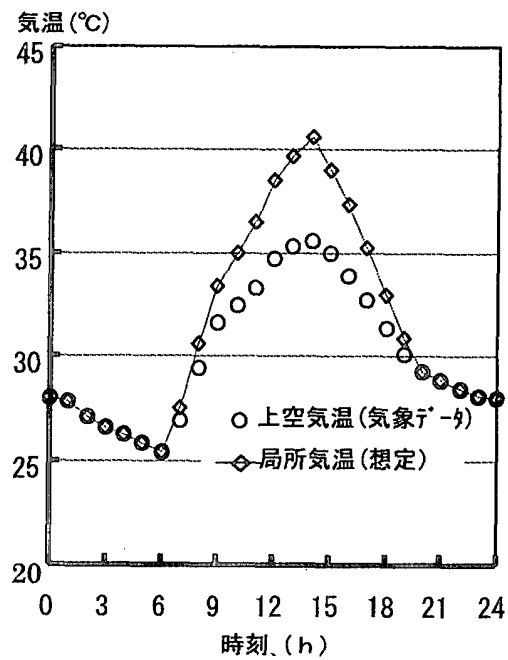

気温の日变化
图 4 都市キャノピー内の気温・風速の空間分布概念

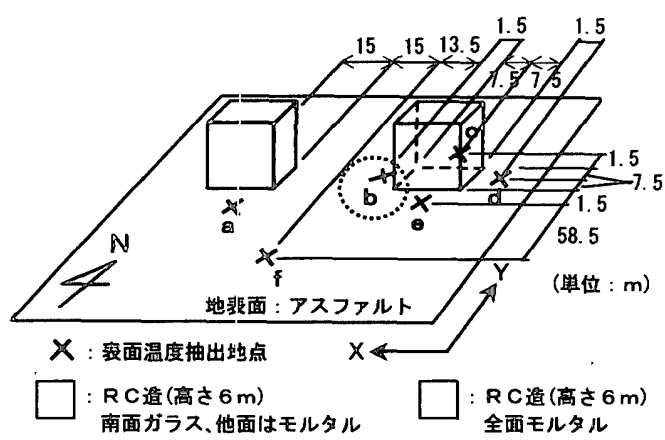

图 5 定時解析検討街区モデルの概要

間内局所の気温（及び風速）の差が著しく大きくなるような場合を 想定して、表面温度が高温となる材料で構成した街区モデル注9) (図 5) において、以下の3つのケースにて図 5 に示す $\mathrm{a} \sim \mathrm{f}$ の各地点 の表面温度算出結果を比較した。(1)既存の方法通り上空の気象デー 夕を用いて表面温度を算出するケース（ケース(1))。(2)図 $6 、 7$ に 示寸ような方法で、上驾気温（及び風速）の時系列变化をもとに局 所気温（及び風速）の 24 時間の時系列データを仮定して与えるケ 一ス (その際、局所の侍系列データは空間内分布一律として与え る;ケース(2) 注 10$)$ 。(3)着目時刻とその 1 時刻ステップ前の $2 つ$ 
の時刻にのみ局所データを与え、それ以外の時刻は、上空の気温 (及 び風速）時系列データを与えるケース（ケース(3)、図6の「採用気 温」、及び図 7 の「採用風速」のデータ参照)。

以上の 3 つケースにて、各ケースの位置付けを把握し、ケース (3)の着目時刻における表面温度がケース(2)に対してどの程度近づ くか検証する。

（1）気温の日変化への対応図6に示寸ような上空気温と局所気温 にて最大約 $5{ }^{\circ} \mathrm{C}$ 差がつくうな場合注10)にて上記の3つのケースにおけ る気温日変化を適用した場合、地点 $\mathrm{a} \sim \mathrm{f}$ のうち、ケース(3)の表面温度予測 結果がケース(2に最も近付かなからた地点bの表面温度変化を図8に示す。 この場合でも着目時刻において0. $5^{\circ} \mathrm{C}$ 程度の差異に収まっており、既往の 方法であるケース(1)比べて、この手法が気温局所分布の考慮に関して有効 であるといえる゙注11)。

（2）風速の日変化への対応上空風速に対して局所風速が約 0.1 倍 となるようなほぼ無風状態に近い場合注10) を想定して、上記の 3 つのケー スにおける風速の日変化を適用した場合、図 9 に示すように、風速の違 いは表面温度の予測結果に大きな相違をもたらす。着目時刻及びそ の 1 時間前の局所風速を考慮した場合、着目時刻において地点 $\mathrm{b} の$

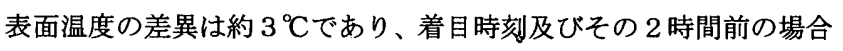
でも $2^{\circ} \mathrm{C}$ 弱の差異がある。また、日射量が減少し、日中に較べて表 面温度と気温との差が小さくなる夕方を対象として比較を行った が、 $2{ }^{\circ} \mathrm{C}$ 程度の差があった注12)。

以上の結果から判断して、着目時刻及び 1 時刻前 (着目時刻の 2 時間前) の局所風速分布を考虑する本手法を採用するに当たって、対象とする上空風 速について上限を設定する必要がある。図 10 に、日中の上空風速の変化幅 を2〜10m/ $\mathrm{s}$ としたときの地点 $\mathrm{b} の$ 各表面温度の変化を示す。ただし、局 所風速を用いない時刻には上空と地表近くの風速比の分布 ${ }^{14)}$ をもとに、上 空風速の0.5倍を空間内一様に与えることとした。の場合、表面温度は、 $10 、 8 、 6 \mathrm{~m} / \mathrm{s}$ の場合は $2^{\circ} \mathrm{C}$ 前後。 $2 、 4 \mathrm{~m} / \mathrm{s}$ の場合は $1^{\circ} \mathrm{C}$ 前後の差とな った。しがって、建築外部空間の居住域レベルでの熱環境改善評価におい ては、ヒートアイランド現象下での風速が比較的低い状㫛が前提であること を考慮し、上空風速が $5 \mathrm{~m} / \mathrm{s}$ 程度までの場合を本手法の対象範用とする住 12 2)。

\section{5. 連成システムの满筑}

\section{1 連成手順の検討}

熱収支シミュレーションと気流シミュレーションの連成手順決 定にあたって、建築外部空間デザインの相違が熱放射環境に直接的 に影響することを考虑すると、熱収支シミュレーションによる表面 温度分布予測は連成使用時でも単独使用時でも目的に応じて柔軟 に使い分けられるシステムとしておく必要がある。従って、気流シ ミュレーションが常に熱収支シミュレーションの前提となる構成 では簡便性及び柔軟性を欠くことになる。

そこで、本連成システムでは図 11 に示すように、まず従来通り、 空間内気温・気流分布一様、初期表面温度气気温とする方法9、1 3) で表面温度分布を求めることとする（図 11 のA 1 )。次に、24 時間 での表面温度算定結果の内、着目時刻とその 1 時刻前の 2 時刻分の 表面温度分布を気流シミュレーションの境界条件として、2 時刻分 の気温・風速分布を求める(図 11 のB 1)。これをもとに熱収支シ ミュレーションによる計算用の気温・気流分布時系列データとして 先に述べた定時解析手法を用いて表面温度分布を求める（図 11 中

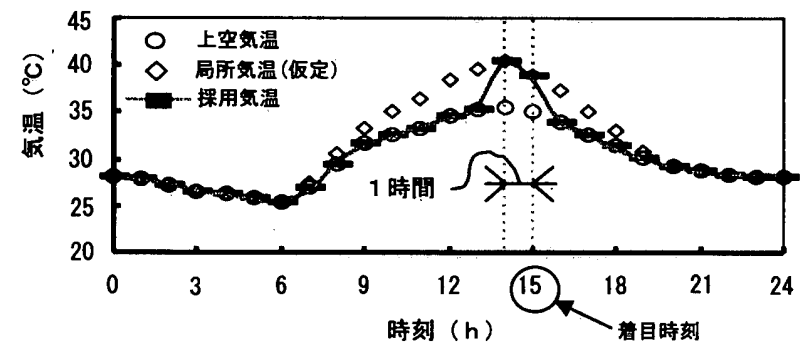

图 6 表面温度算出時の着目時刻前後の局所気温の導入概念

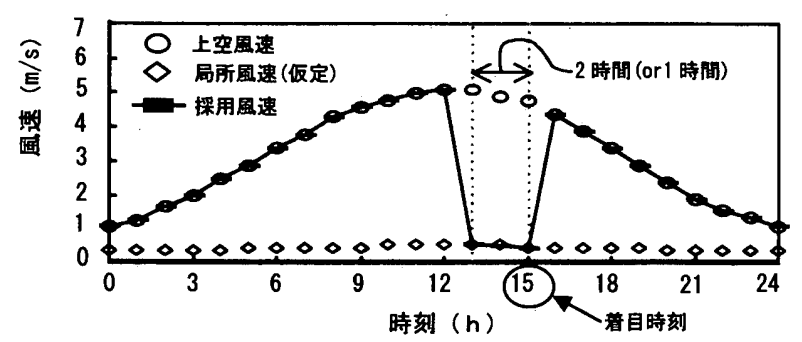

图 7 表面温度算出時の着目時刻前後の局所風速の㬴入概念

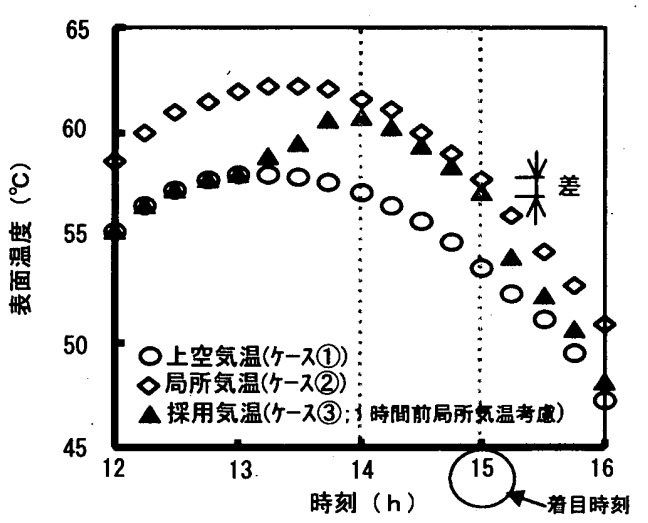

图 8 局所気温考慮時の表面温度の推移(地点 b )

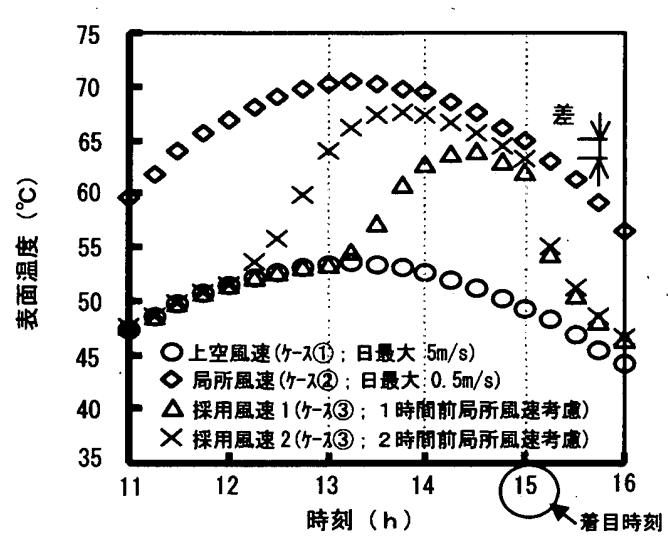

図 9 局所風速考慮時の表面温度の推移(地点 b)

のA 2): 以下、順次 B 2、A 3 といった繰り返しとする。

\section{2 妥当な連成反復回数の検討}

連成前後における空間全表面による面平均表面温度差、及び気温 差、平均風速差の空間平均値を平均収束判定値として、妥当な連成 反復回数の抽出のための評価を行った。各種街区モデルの中でも図 12 に示すように、空間内にて表面温度、気温、平均風速の各分布に て大きな相違が発生すると考えられる街区モデル注13）を設定し、 図 11 に示す計算を行った注14)。表 1 に、着目時刻（14:00）におけ る各物理量の平均収束判定值の推移を示す。 
図 11 のA 1 では気温・風速の空間分布を考虑しないため、A 1 〜 A 2 で約 $3^{\circ} \mathrm{C}$ 表面温度差が生じた。それに伴い、B 1 ～B 2 では、 気温の平均収束判定值は約 $0.1^{\circ} \mathrm{C}$ 以下であるが、場所によって約 1 〜 ${ }^{\circ}$ Cの差となった。A $2 \sim \mathrm{A} 3$ では、空間内での表面温度の大き な差はほとんど無く、また、気温についても空間平均ではほとんど 差異が見られず、比較的温度差がつく場所でも約 $0.1^{\circ} \mathrm{C}$ 近くまで低 下した。なお、平均風速については、A $1 \sim \mathrm{A} 2 、 \mathrm{~A} 2 \sim \mathrm{A} 3$ いず れもほとんど差異が見られなかった注15)。以上より、表面温度は気 温・風速の変化の影響を受けるが、気温、風速は表面温度の変化の 影響を全空間で直接大きく受ける傾向にはなく、また、設計支援が 目的であることから、表面温度分布、気温・気流分布の予測結果を 総合的に評価する場合は、3回目の気流シミュレーション以降を省 略し、A 3 をもって連成を終了させることとした。

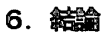

建築外部空間デザインの設計支援を目的とした熱収支・気流連成 シミュレーション手法の開発を行った。本手法は、熱収支シミュレ ーションと気流シミュレーションから構成されており、設計プロセ スと要求される熱環境の評価性能によって、柔軟なツール構成をも って対応可能とするといった特徵を持つ。本連成手法開発にあたり、 (1)熱収支シミュレーションによる外部空間の全表面温度算出にあ たっての気温、風速の空間分布の考慮方法、(2)連成の具体的実施手 順と連成反復回数などについての方法論を提案し、妥当性を確認し た。今後は、熱収支シミュレーション、気流シミュレーションの両 者に対する $3 \mathrm{D}-\mathrm{CAD}$ A よる空間形状の共通入力化方法の構築 等について検郡を行っていく。

\section{【謝辞】}

本研究は、文部科学省科学研究費、平成 12 年度基盤研究 B (2) (代 表：梅干野昆）の補助を受けた。また、本研究は、修士論文として 取り組んだ当時大学院生東山純也氏の成果でもある。ここに記して 感謝する。

注 1）例えば、住棟間・敷地内通路に、高木の薣木群を配し日射遮蔽を 行った場合、予湘評価の結果、熱放射環境は大幅に改善されるものの平 均風速が低減し、平均風速の下がり幅によっては SET*評価では快適 性が低下するといった可能性もあり得る。一方、既往の実測結果 ${ }^{8)}$ から、 日射遮蔽下における低風速時の乱れの強さの快適性への寄与が認めら れることを考慮すると、SE T * 等快適性指標だけによる建築外部空間 デザインの判断には注意を要する。乱れの強さや短波長放射などを考慮 したより実態に即した総合快適性指標の実用化が望まれるが、現時点で は未だ十分ではない。従って、パーヨ゙ラ、樹木等の空間構成要素の相違 が熱放射環境に及ぼす影響を評価したい場合などは、表面温度 (MRT) にても、実務上デザインの相違の判断は可能であり、さらに SE T * 等 快適性指標にて補足を図るといった評価の方法がより見実的と考える。 注 2 ）熱収支シミュレーション手法は、3 D-C A Dによる空間形状入 力（及び 3 次元均等メッシュデータ化）、及び計算結果のグラフィック 表示が可能である。また、複雑な樹冠形状、庇・パーヨ゙ラなどの小スク

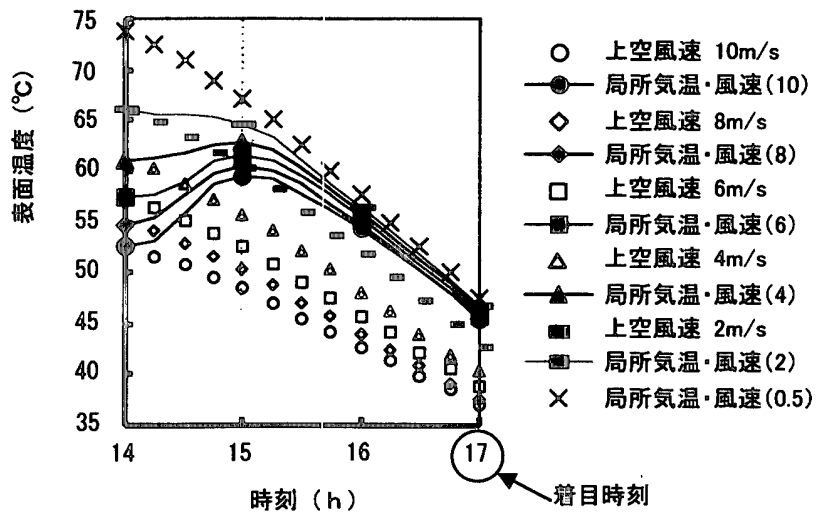

图 10 上空風浐の橾いによる表面温度变化の相違(地点 b )

\begin{tabular}{|c|c|}
\hline $\begin{array}{c}\text { 熱収支シミュレーション } \\
\text { LINEーA }\end{array}$ & $\begin{array}{c}\text { 気流シミュレーション } \\
\text { LINEーB }\end{array}$ \\
\hline A 1 (A:表面温应非湗) & 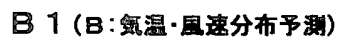 \\
\hline 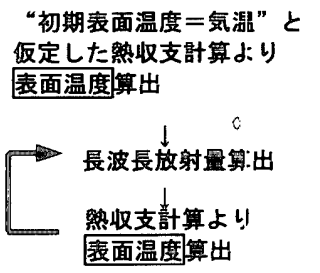 & 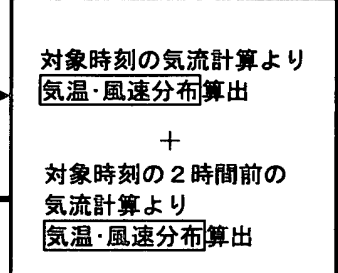 \\
\hline A 2 & 82 \\
\hline A 3 & B 3 \\
\hline A 4 & - \\
\hline
\end{tabular}

图 11 連成システムの概要

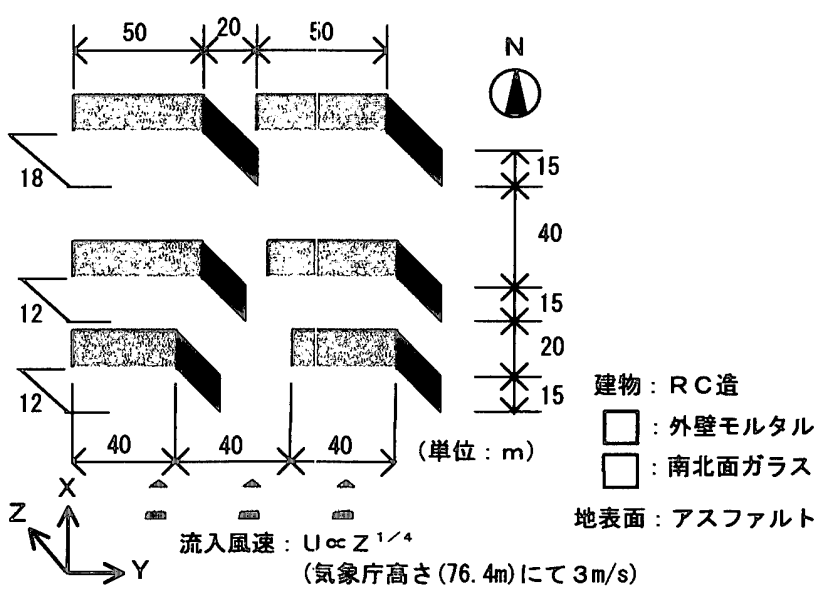

图 12 連成反復回数検討用街区モデルの概要

表 1 篃目時刻 $(14: 00)$ における平均收束判定值の推移

\begin{tabular}{|c|c|c|}
\hline 判定対象成 & $\begin{array}{c}A 1 \sim A 2 \\
(B 1 \sim B 2)\end{array}$ & $\begin{array}{l}A 2 \sim A 3 \\
(B 2 \sim B 3)\end{array}$ \\
\hline 聚面温度盖 $\left({ }^{\circ} \mathrm{C}\right)$ & 3. 2 & 0.2 \\
\hline 気温差 $\left({ }^{\circ} \mathrm{C}\right)$ & 0.071 & 0.014 \\
\hline 風速差 $(\mathrm{m} / \mathrm{s})$ & 0.013 & 0.008 \\
\hline
\end{tabular}


一ルな空間構成要素の形状を反映した熱放射環境の比較検討が出来る よう空間全表面を $0.2 \mathrm{~m}$ 均等メッシュによりメッシュ化を行っており、 メッシュ毎に各表面における受熱日射量（鏡面反射、抬散反射含む)、 大気放射量、対流熱伝達量などを組み込んだ 1 次元熱伝導方程式を基本 として、周辺地物からの長波長放射も併せた熱収支計算によって空間全 表面温度を算出する。これらの機能は、本研究で提案する設計支援を目 的とした予測評価手法構築に当たって必要不可欠であり、1 次元熱収支 モデルを基にした谷本らクのモデルをはじめ、その他の熱収支計算手法 では、前述した設計支援上の必要機能を満足し難い。

各メッシュにおける対流熱伝達量の算出にあたってては、第 1 段階とし て、参照する気温、風速は空間内（都市キャノピー内）の分布一様とし て、気象データの平均風速（U) をもとにJurges の式 $(\mathrm{U} \leqq 4.9 \mathrm{~m} / \mathrm{s}$; $\left.\alpha \mathrm{c}=6.2+4.3 \mathrm{U} 、 \mathrm{U}>4.9 \mathrm{~m} / \mathrm{s} ; \alpha \mathrm{c}=7.6 \mathrm{U}^{0.78}\right)$ にて対流熱伝達率 $(\alpha \mathrm{c})$ を求めている。等収支シミュレーション手法の詳細は参考文献 （9）を参照されたい。

注3) 図 1 に示した各設計プロセスと設計支援手法（予測評価手法）の 関わりは、設計に際して、一般的に基本構想〜実施設計といった段階的 プロセスが踏まれる場合の予測評価手法の関わりの一例である。プロジ エクトによって、踏㠤される設計プロセスは多様であり、基本構想段階 がない、基本設計と実施設計が時間差なく進渉するといったケースもあ りうるため、設計プロセス進渉に対する図 1 中「予測評価その $1 \sim 3 」$ の関わり方は、基本設計で「予測評価その $3 」 か ゙$ 実施されるなど、これ 以外にも多様に考えられる。

注 4$) \cdot \mathbf{k}-\varepsilon$ 乱流モデルについては、様々なモデルが提案され、各モデル の予測精度について、単体建物䞤りの流れ場を対象にしたベンチマーク テスト ${ }^{15)}$ が実施され比較検討が進んでいる。しかしながら、本研究で 対象とするような、樹木と建物が複雑に配置されるような流れ場に関す る各モデルの予㨽精度の位置づけは充分精査されていない。従って、本 連成手法では、通常の標準型 $\mathrm{k}-\varepsilon$ モデルを採用し、下記の式 $(1) \sim(3)$ に示す樹木の力学的影響 $\left.{ }^{5} 、 16\right)$ を組み込んだモデルを使用した。組み込 みにあたうて、運動方程式に抗力項（式(1))のみを組み込んだ場合と、 抗力項 (式(1))、及び $\mathbf{k} 、 \varepsilon$ 方程式に式 (2)、（3）を組み込んだ場合と で風洞実験結果と比較し、予測精度の検証を行っている ${ }^{17}$ 。

なお、連成手法構築にあたり、実務での汎用性を考慮するに現段階で は、標準型 $\mathrm{k}-\varepsilon$ モデルの採用が妥当と考えるが、その他の $\mathrm{k}-\varepsilon$ 乱流モ デルを採用した場合の本モデルとの相違については、4、5章に述べる 連成手法構筑のための各種方法論を適用した比較検討を行う必要があ り、今後の検討課題である。

$$
\begin{aligned}
& F_{d}=\rho a C_{d} u_{j}^{2} \\
& \mathrm{k}=C_{d} a(x, y, z)\left(\left\langle u_{j}\right\rangle^{2}\right)^{3 / 2} \\
& \varepsilon=\frac{\varepsilon}{\mathrm{k}}\left\{C_{d} a(x, y, z)\left(\left\langle u_{j}\right\rangle^{2}\right)^{3 / 2}\right\}
\end{aligned}
$$

$F_{d}$ : 樹木による抗力項、 $\left\langle u_{j}\right\rangle$ : 平均風速 $(j=1,2,3) 、 C_{d}$ : 抵抗係数、 $\rho:$ 空気密度 $\left[\mathrm{g} / \mathrm{m}^{3}\right] 、 a(x, y, z):$ 葉面積密度 $\left[\mathrm{m}^{2} / \mathrm{m}^{3}\right]$

注 5 ) 熱収支シミュレーションでは小スケールの空間構成要素の熱放射 環境への影響を評価するため、0. $2 \mathrm{~m}$ での 3 次元均等メッシュデータ化 を行う。一方、気流シミュレーションは対象とする空間形状の大きさ・ 複雑さに応じてメッシュサイズ・形状は多様となる。従って、メッシュ 化を前提とした場合、両者に共通の $3 \mathrm{D}-\mathrm{CAD}$ ～空間形状入力の 方法構築は今後の課題である。
注 6) 本連成手法では、建築外部空間の快適性の高精度な予測評価より も、空間デザインの熱的評価による設計支援に主眼をおいているため、 空間内の潜熱移動までの連成とはしていない。しかしながら、樹木、芝、 裸地の蒸散作用については、梅干野ら ${ }^{18)} 、$ 片山ら ${ }^{19)}$ の実測結果を元に した気温と日射量による表面温度の回帰式を熱収支シミュレーション に組み込み、空間全表面温度の算出上、蒸発潜熱を考庶している。外部 空間デザインの評価上、空間内の潜熱移動の簡易な組み込みは今後の検 討課題である。

注 7 ) 熱収支シミュレーションにおいて、0.2m均等メッシュを用いて 複雑な空間形状の再現性を高めている関係上、本来であれば、各空間構 成要素の材料・形状等の相違を考虑した高精度な対流熱伝達率算出のモ デル化が必要である。しかしながら現段階では検討の過程にあるため、 汎用されている方法として Jurges の式に拠った。デザインの相対的比 較においては特に支障ないものと考えるが、今後の検討課題である。 注 8）表面温度算出のため、簡易に気温・風速の局所分布を考慮した時 系列入カデータを作成する方法としては、このほか、以下のような方法 等が考えられる。(1)気流シミュレーションにて着目時刻の気温・風速分 布を算出する。(2)着目時刻における上空気象データと各局所との気温比、 風速比を求め、上空気象データの時刻変化より、各局所每に 24 時間分 の気温・風速の時刻別データを作成する。本方法の場合、上空と局所と の気温比・風速比が日中常に成立することが前提となる。気温比の成立 については、いくつか既往の実測報告 ${ }^{20)}$ も散見するが、樹冠配置も含 めた複雑な空間形状の中での各局所と上空気象データとの間の時刻毎 の相関関係については明確になっておらず今後の検討課題である。一方、 風速比については一定風向下での成立 ${ }^{14)}$ は確認されているものの、上 空気象データ上、本来、風向も時刻変化して一定ではなく、風向変化に よって風速比そのものが大きな影響を受ける。以上より、気温比・風速 比の常時成立を原則前提とせず、風向も含め着目時刻と 1 時刻前の上空 気象データより局所分布を求める「定時解析手法」のほうがより実現象 に対して現実的である。ただし、「定時解析手法」において、着目時刻 の 1 時刻前を 2 時間前とする場合については、着目時刻直前の 1 時間前 の局所毎の気温・風速に限っては、本方法により便宜的に算出している。 注 9) 街区モデルを熱容量が大きくかつ反射率の高い材料によって構成 し、また、樹木等による日射遮蔽が全く無い空間とすることで、熱放射 環境が居住域気温分布に影響を及ぼしやすい状況にして、夏期の熱環境 が劣悪になる場合を前提としている(なお、日射吸収率はモルタル、ア スファルトいずれも 0.8 とした)。その上で街区モデル内に、直達日射 の影響を昼中通じて受けやすい地点、日射遮蔽の影響を受けやすい地点、 ガラス面からの鏡面反射の影響を受けると想定される地点等、実際の街 区にて熱放射環境的な特徽が予想される地点を $\mathrm{a} \sim \mathrm{f}$ まで設定して表 面温度を算出し検討を行った。熱放射環境改善が考慮された街区モデル゙ 等についても今後同様に確認を行っていきたい。

注 10）上空気象データには、東京の 8 月の晴天日の標準気象データを用 いた。また、居住域レベルにおける局所データは、大幅な差異がみられ る状況を想定して、(1)上空の気温時系列データに対して気温は解析対象 時刻で約 $5{ }^{\circ} \mathrm{C}$ 差、(2)また、上空の風速時系列データに対して風速は最大 0.1 倍程度の差をつけたデータを作成し、空間内ではこのような局所気 温・風速が一様に分布するとして与えている。実際には、空間内の全居 住域でこのような大きな差異がつくことは考えにくいが、定時解析手法 の妥当性検証のため、本前提のような厳しい条件の場合を想定した。な お、前述以外の水平面全天日射量等は、標準気象データをもとに与えた。 注 11)「 1 時刻前二着目時刻一 2 時間」をケース(3)とした場合、地点 $\mathrm{b} の$ ケース(2)との表面温度差は $0.5^{\circ} \mathrm{C}$ 以下であった。1 時刻前の時間を長く するほど、ケース(2)、(3)の表面温度差は小さくなるが、”注 8)”に示 
した方法を踏裂することになり、定時解析手法から外れ問題が残る。 注 12）局所風速考慮時、「 1 時刻前=着目時刻一 3 時間 or 4 時間」を久

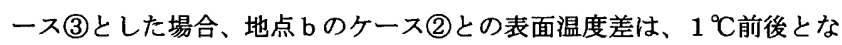
るが、”注 11）”に示した気温の場合と同様、本定時解析手法から外れ 問題が残る。風速に関する定時解析手法の採用に当たり、特に風速は対 流熱卮達に大きな影響を及ぼすことから、適用可能䇩囲についての確認 を行った。

注 13) 連成反復計算において、第 1 回目の計算 (表 1 中 A 1 ) 結果と、第 2 回目の計算 (表 1 中 A 2 ) 結果の差が大きいほど計算時間の短縮化に 影響を及ぼす。従って、表面温度分布幅、及び気温・風速の空間分布幅 が出来るだけ大きくなることを考慮して、建物間北面側が日影になる時 間帯が長く、かつ、南北方向の敷地内通路は風が通り抜け、建物間は気 流が停滞し、建物間の北面側に熱気溜りが生じやすい空間形状とした。 なお、街区の領域外の状況は全て空気 $\left(33^{\circ} \mathrm{C}\right)$ として計算を行った。 注 14) 計算条件の概要は以下のとおり。

・気象データ : 東京の 8 月の晴天日の標淮気象データ

・日射吸収率：モルタル、アスファルトいずれも 0.8

・気流解析の計算条件 :

\begin{tabular}{|l|l|}
\hline 流入条件 & $\begin{array}{l}U \propto Z^{1 / 4}(Z=74.6 \mathrm{~m} \text { にて 3m/s)、 } \\
\varepsilon=\mathrm{C}_{\mu}{ }^{1 / 2} k \partial U / \partial Z 、 C_{\mu}=0.09\end{array}$ \\
\hline 壁面条件 & 一般化対数則 \\
\hline 上空・側面 & Free SIip \\
\hline
\end{tabular}

注 15）気流シミュレーションを先行して行う場合については、以下の手 順となる。まず、解析対象時刻の上空気象データの風速をもとに、気流 シミュレーションにて等温解析を行う。算出した風速分布とともに、空 間内気温分布一様、初期表面温度二気温として、時刻別表面温度分布を 熱収支シミュレーションにて算出する。次に、解析対象時刻とその 1 時 刻前の表面温度分布を気流シミュレーションの境界条件として、2 時刻 分の気温・風速分布を求める。これをもとに熱収支シミュレーションに よる気温・気流分布時系列データとして定時解析手法を用いて表面温度 分布を求める。本手順を適用した結果、A 1 ～A 2 では、空間全表面に よる面平均表面温度差は $1{ }^{\circ} \mathrm{C}$ 程度となり、熱収支シミュレーション先行 の場合よりも表面温度差は低減化した。しかしながら、場所によっては、 $2{ }^{\circ} \mathrm{C}$ 以上の表面温度差があることから、A 2 で連成を終了できず、A 2 〜A 3すなわち 3 回目の気流シミュレーションが必要になり、計算負荷 削減に奇与しない。従って、連成システム構筑にあたっては、熱収支シ ミュレーション単独での使用の可能性も考虑して、まず、熱収支シミュ レーションにて表面温度分布を求めるのを原則とした。

一方、図 12 の街区モデルよりも空間内の風速分布がより偏在化する 空間形状を対象として図 11 の手順にて連成した場合、A 1〜A 2 の表 面温度差は表 1 の結果よりも大きくなる傾向にあるが、A 2 A 3 の差 がA 1 ～A 2 の差に較べて大幅に低下する傾向は概ね同様であった。

\section{【本研究に関連する既器表文献】}

1）山村真司、梅干野泉、松永恒雄、北村規明 : 熱収支・気流連成シミ ニレーション手法の提案 (その1) 建築外部空間のバイオクリマテ イックデザインのための設計支援手法(その1)、日本建築学会学術 講演梗概集、pp.891 892、1999 年 9 月、(その 2)、同上、pp.893 〜894、(その 3)、同上、pp.895〜896

【引用文献】

1）谷本潤、Douglas BALKOM、片山忠久、萩島 理 : LOW-ENERGY BUILDING 設計支援ツールとしての ENERGY-10 に関する報告、 日本建策学会技術報告集、第 9 号、pp.153 158、1999 年 12 月

2）嗵口佳樹、宇田川光弘、佐藤誠、木村健一：建築屋外における日射 と長波長放射の計算モデルー周囲環境を考慮した住宅の熱負荷シ
ミュレーションに関する研究一、日本建策学会計画系論文集、第 544 号、pp.9 15、2001 年 6 月

3）村上周三、持田灯 : 関東地方における土地利用状況の変化と流れ 場・温度場の関係 Mellor-Yamada 型の都市気候モデルによる局地 気像解析、日本建築学会計画系論文集、第 491 号、pp.31 39、1997 年 1 月

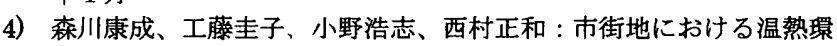
境の予測・評価手法の検討 Rapid Prototype 技術の適用、日本建 築学会学術講演梗概泰、pp.869 872、1997 年

5）吉田伸治、大岡龍三、持田灯、富永禎秀、村上周三 : 樹木モデルを 組み込んだ対流・放时・湿気輸送連成解析による樹木の屋外熱環境 緩和効果の検郡、日㶱建勧学会計画系論文集、第 536 号、pp.87〜 $94 、 2000$ 年 10 月

6）原山和也、村上周三、吉田伸治、大岡龍三、持田灯 : 非定常な対流 放射・伝導を考慮した屋外温熱環境予測評価手法に関する研究(その 1) 実在街区を対象とした非定常の放射・伝導解析の精度検証、日本 建築学会学術講演梗概集、pp.925 926、2001 年 9 月

7）谷本潤、林徹夫、片山忠久、大濱淳司、笠間幹雄 : 建築一都市一土 㙵連成系モデルによる都市高温化要素の定量的比較に関する研究 第 1 報 理論構成手法と基本解、日本建築学会計画系論文集、第 504 号、pp.87 93、1998 年 2 月、をはじめとして、同計画系論文集、 第 510 号、pp.53 60、1998 年 8 月、同計画系論文集等

8）例えば、斎藤雅也、宿谷昌則：「涼しさ」を感じる気流に関する屋 外での実測とその解新、日本建築学会計画系論文集、第 523 号、pp.39 $\sim 44 、 1999$ 年 9 月

9）山村真司、梅干野㫤、浅輪貴史 : 建築外部空間デザインの設計支援 を目的とした熱放射擐境の予測手法の開発、日本建築学会計画系論 文集、第 554 号、pp.85 92、2002 年 4 月

10）例えば、P·G·ロウ著、奥田健二訳 : デザインの思考過程、鹿島出版 会、1993

11）例えば、和田浩一、画村伸也、高橋和也、周博、高橋鷹司 : 3D-CAD を用いた設計手法に関する研究·設計教育における淮実験的試みそ の 2、日本建築学会計画系論文集、第 549 号、pp.169 176、2001 年 11 月

12）吉田伸治、村上周三、持田灯、大岡龍三、富永禎秀、金相琟：対流 放射・湿気輸送を連成した屋外環境解析に基づく緑化の効果の分析、 日本建築学会計画系淪文集、第 529 号、pp.77 84、2000 年 3 月

13) Akinaru Iino, Akira Hoyano: Development of a method to predict the heat island potential using remote sensing and GIS data, ENERGY AND BUILDING, pp.199 205, 1996

14) 新建築学大系編集委貴会: 新建築学大系 8 自然環境 第 3 章風論、 彰国社、1989 年 5 月

15）環境工学委員会・空気環境小委員会・風環境数值計算 WG：CF D を利用した高層建物周辺の風環境予測手法の開発一その 1 ベン チマークテストによる各種 $\mathrm{k}-\varepsilon$ モデルの相互比較一、日本建築学会 技街報告集、第 12 号、pp.119 124、2001 年 1 月

16) Yamada T. : A Numerical Model Study of Turbulence Airflow in and above a Forest Canopy, J. of Meteorol. Soc. Japan 60, pp439 $\sim 454,1982$

17）山村真司、梅干野泉、松永恒雄、白澤多一、浅輪貴史、清水敬示 : 熱環境に配應した建築外部空間の実現化を目的とした設計支援手 法(その 3 ) 標準型 $\mathrm{k}-\varepsilon$ モデルを用いた樹木が通風効果に及ぼす影響 の予測、日本建築学全学術講演梗概集、pp.1135 1136、2000 年 9 月

18）梅干野昆、荻原賢二:屋上の芝生植栽による照り返し防止・焼け込 み防止効果、日本建筑学会環境工学論文集、pp.133 140、昭和 58 年 11 月

19）下川宰司、片山忠久、林徹夫、谷本潤、何平、池沢紀幸 : 樹木のあ る街路の熱環境予測をその 5、実測に基づく樹冠部熱特性に関する検 討、日本建築学会学術講演梗概集、pp.131 132、1996 年 8 月

20）例えば、中村泰人、平岡久司、西村浩一：市街地空間における気温 分布性状に関寸る実焕的研究、日本建筑学会計画系論文集、第 364 号、pp.48〜55、昭和 61 年 6 月

（2002年 1 月 9 日原稿受理，2002年 7 月 5 日採用決定） 